\title{
Fish Red Blood Cells Modulate Immune Genes in Response to Bacterial Inclusion Bodies Made of TNF $\alpha$ and a G-VHSV Fragment
}

\author{
Sara Puente-Marin ${ }^{1,2}$, Rosemary Thwaite ${ }^{3}$, Luis Mercado ${ }^{4}$, Julio Coll ${ }^{5}$, Nerea Roher ${ }^{3 \dagger}$ and \\ Maria Del Mar Ortega-Villaizan ${ }^{1,2 * t}$ \\ ' Departamento de Bioquímica y Biología Molecular, Instituto de Biología Molecular y Celular (IBMC), Universidad Miguel \\ Hernández (UMH), Elche, Spain, ${ }^{2}$ Departamento de Bioquímica y Biología Molecular, Instituto de Investigación, Desarrollo e \\ Innovación en Biotecnologîa Sanitaria de Elche (IDiBE), Universidad Miguel Hernández (UMH), Elche, Spain, ${ }^{3}$ Department \\ Biologia Cellular, Fisiologia Animal i Immunologia, Institut de Biotecnologia i de Biomedicina (IBB), Universitat Autònoma de \\ Barcelona (UAB), Barcelona, Spain, ${ }^{4}$ Grupo de Marcadores Inmunológicos, Laboratorio de Genética e Inmunología \\ Molecular, Instituto de Biología, Pontificia Universidad Católica de Valparaíso (PUCV), Valparaíso, Chile, ${ }^{5}$ Departamento de \\ Biotecnología, Instituto Nacional de Investigación y Tecnología Agraria y Alimentaria (INIA), Madrid, Spain
}

OPEN ACCESS

Edited by:

Jun-ichi Hikima,

University of Miyazaki, Japan

Reviewed by:

Yong-An Zhang,

Huazhong Agricultural

University, China

Motoshige Yasuike,

Japan Fisheries Research and

Education Agency, Japan

*Correspondence:

Maria Del Mar Ortega-Villaizan

mortega-villaizan@umh.es

†These authors have contributed equally to this work

Specialty section:

This article was submitted to

Comparative Immunology,

a section of the journal

Frontiers in Immunology

Received: 02 June 2018 Accepted: 24 April 2019

Published: 22 May 2019

Citation:

Puente-Marin S, Thwaite $R$ Mercado L, Coll J, Roher N and Ortega-Villaizan MDM (2019) Fish Red Blood Cells Modulate Immune Genes

in Response to Bacterial Inclusion

Bodies Made of TNF $\alpha$ and a G-VHSV

Fragment. Front. Immunol. 10:1055.

doi: 10.3389/fimmu.2019.01055
Fish Red-Blood Cells (RBCs) are nucleated cells that can modulate the expression of different sets of genes in response to stimuli, playing an active role in the homeostasis of the fish immune system. Nowadays, vaccination is one of the main ways to control and prevent viral diseases in aquaculture and the development of novel vaccination approaches is a focal point in fish vaccinology. One of the strategies that has recently emerged is the use of nanostructured recombinant proteins. Nanostructured cytokines have already been shown to immunostimulate and protect fish against bacterial infections. To explore the role of RBCs in the immune response to two nanostructured recombinant proteins, TNF $\alpha$ and a G-VHSV protein fragment, we performed different in vitro and in vivo studies. We show for the first time that rainbow trout RBCs are able to endocytose nanostructured TNF $\alpha$ and G-VHSV protein fragment in vitro, despite not being phagocytic cells, and in response to nanostructured TNF $\alpha$ and G-VHSV fragment, the expression of different immune genes could be modulated.

Keywords: erythrocytes, red blood cells, bacterial inclusion bodies, TNF $\alpha$, VHSV glycoprotein G, immune response

\section{INTRODUCTION}

Fish red blood cells (RBCs) are nucleated cells that contain organelles in their cytoplasm unlike those of mammals (1). Apart from their well-known role in gas exchange, recently a set of new biological roles for nucleated RBCs related to the immune response have been reported. Nucleated RBCs are able to phagocytose and act as antigen presenting cells $(2,3)$. They can respond to different pathogen associated molecular patterns (PAMPs), modulate leukocyte activity, release cytokine-like factors $(4,5)$ and lately they have been implicated in the response to viral infections [reviewed in Nombela and Ortega-Villaizan (6)].Considering all of these findings, the potential role of RBCs in the immune system of fish takes on a new, interesting perspective.

To date, one of the best strategies for preventing and controlling viral diseases in aquaculture is DNA vaccination. However, it remains unclear which mechanisms are responsible for this protection (7). The search for new, safe and effective vaccines has become a priority in this field. Among fish viral diseases, viral hemorrhagic septicaemia (VHS) is a lethal infectious fish disease 
caused by viral hemorrhagic septicaemia virus (VHSV), which affects over 50 species of fish, freshwater and marine, in the northern hemisphere (8).

As an alternative to overcome the safety problems associated to live attenuated or DNA vaccines, bacterial inclusion bodies (IBs) nanostructured recombinant proteins have been presented as a new option for vaccination (9). IBs are per se strong stimulants of the fish immune system and have a set of characteristics which make them an attractive alternative: they are mechanically stable, production is scalable and costeffective, they are non-toxic biomaterials and are composed of recombinant proteins. The latter means they are an adaptable prototype, which could be a good platform for vaccination against a wide range of diseases $(9,10)$. Such nanostructured recombinant proteins have already been shown to protect fish against bacterial infection (9).

In this paper, we show for the first time the response of rainbow trout RBCs in vitro and in vivo to two different nanostructured recombinant proteins, recombinant rainbow trout tumor necrosis factor alpha protein $\left(\mathrm{IB}^{\mathrm{TNF} \alpha}\right)$ and recombinant fragment 16 of the glycoprotein G of VHSV (11) $\left(\mathrm{IB}^{\mathrm{frg} 16 \mathrm{G}-\mathrm{VHSV}}\right)$. In response to recombinant protein IBs, RBCs were able to modulate the expression of interferon related genes, the myxovirus resistance $(m x)$ gene and genes related to antigen presentation (cluster of differentiation 83 [ $c d 83$ ], major histocompatibility class I $[\mathrm{mhcI}]$ and major histocompatibility class II $[m h c I I])$. Genes related to antioxidant response (natural killer enhancing factor [nkef] and glutathione S-transferase pi 1 gene [gstp1] and cytokines (interleukin $1 \beta$ [il1 $\beta$ ], interleukin $12 \beta$ [il12 $\beta$ ], interleukin 6 [il6], interleukin 2 [il2], and interleukin 8 [ils]) were also modulated. Interestingly, $\mathrm{IB}^{\mathrm{TNF} \alpha}$ mostly down-regulated in vitro and in vivo immune genes expression in RBCs meanwhile $\mathrm{IB}^{\text {frg } 16 \mathrm{G}-\mathrm{VHSV}}$ mainly showed an upregulation trend.

\section{MATERIALS AND METHODS}

\section{Production of IBs, Purification, Quantification, and Fluorescent Labeling}

Nanostructured proteins were produced in E. coli following the method described in Torrealba et al. (9) and Thwaite et al. (12). In short, E. coli transformed with the plasmid of interest was cultured in LB with the appropriate antibiotic and recombinant protein expression was induced at $\mathrm{OD}_{550 \mathrm{~nm}}$ 0.5-0.8 with $1 \mathrm{mM}$ IPTG (Panreac, Barcelona, Spain). IBs were isolated after $3 \mathrm{~h}$ additional incubation at $37^{\circ} \mathrm{C}$ via enzymatic and mechanical disruption of the cells according to Torrealba et al. (10), followed by sterility monitoring (12). Purified nanoparticles, named here $\mathrm{IB}^{\text {frg } 16 \mathrm{G}-\mathrm{VHSV}}, \mathrm{IB}^{\mathrm{TNF} \alpha}$ and $\mathrm{IB}^{\mathrm{iRFP}}$ [an inclusion body made of a non-immunogenic phytochrome-based near infra-red fluorescent protein (iRFP) with the excitation/emission maxima at $690 / 713 \mathrm{~nm}$ (13)], were stored at $-80^{\circ} \mathrm{C}$ until use. Quantification was performed by western blot using an anti-His-tag antibody (Genscript, Piscataway, NJ, USA) and calculating the protein concentration from a standard curve using Quantity One software (Biorad,
Hercules, CA, the USA). For flow cytometry or confocal microscopy, $\mathrm{IB}^{\text {frg } 16 \mathrm{G}-\mathrm{VHSV}}$ and $\mathrm{IB}^{\mathrm{TNF} \alpha}$ were conjugated with fluorescent Atto-488 NHS ester (Sigma-Aldrich) following manufacturer's instructions.

\section{Animals}

Juvenile rainbow trout (Oncorhynchus mykiss) were obtained from a commercial farm (Piszolla S.L., Cimballa Fish Farm, Zaragoza, Spain), and maintained at the University Miguel Hernandez (UMH) facilities at $14^{\circ} \mathrm{C}$, fed daily with a commercial diet (Skretting, Burgos, Spain). Prior to experiments, fish ware acclimatized to laboratory conditions for 2 weeks. Separately, adult rainbow trout were maintained at the Universitat Autònoma de Barcelona (UAB) at $17 \pm 1^{\circ} \mathrm{C}$, fed daily with a commercial diet. The number of individuals used in each experiment is indicated by an " $n$ " in each figure legend.

\section{Cell Cultures}

Rainbow trout RBCs were obtained from peripheral blood of fish sacrificed by overexposure to tricaine (tricaine methanesulfonate, Sigma-Aldrich) (0.3 g/L). Peripheral blood was sampled from the caudal vein using insulin syringes (Nipro, Bridgewater, NJ, USA) as previously described (14). RBCs were purified by two consecutive density gradient centrifugations (7,206 g, Ficoll 1.007; Sigma-Aldrich). Purity of RBCs of $99.9 \%$ was estimated by optical microscopy (Figure S1). Purified RBCs were cultured with RPMI-1640 medium (Dutch modification) (Gibco, Thermo Fischer Scientific Inc., Carlsbad, CA) supplemented with 10\% fetal bovine serum (FBS) gamma irradiated (Cultek, Madrid, Spain), $1 \mathrm{mM}$ pyruvate (Gibco), $2 \mathrm{mM}$ L-glutamine (Gibco), $50 \mu \mathrm{g} / \mathrm{mL}$ gentamicin (Gibco) and $2 \mu \mathrm{g} / \mathrm{mL}$ fungizone (Gibco), $100 \mathrm{U} / \mathrm{mL}$ penicillin and $100 \mu \mathrm{g} / \mathrm{mL}$ streptomycin (SigmaAldrich) at a density of $10^{6}$ cells $/ \mathrm{mL}$ at $14^{\circ} \mathrm{C}$.

\section{Uptake of IB ${ }^{\mathrm{TNF} \alpha}$ and IB ${ }^{\text {frg16G-VHSV }}$ by RBCs}

RBCs cultures were treated with fluorescent $\mathrm{IB}^{\mathrm{TNF} \alpha}$ or $\mathrm{IB}^{\text {frg16G-VHSV }}$ at different concentrations and uptake was analyzed by flow cytometry using a FACSCanto ${ }^{\mathrm{TM}}$ cytometer (BD Biosciences, Madrid, Spain) (10.000 total events), at different times post-treatment. For dose-response evaluation, IBs at concentrations of 10,20 and $50 \mu \mathrm{g} / \mathrm{mL}$ were added to RBCs cultures for $24 \mathrm{~h}$. For time-course experiments, RBCs were treated with $80 \mu \mathrm{g} / \mathrm{mL} \mathrm{IB}^{\mathrm{TNF} \alpha}$ or $160 \mu \mathrm{g} / \mathrm{mL} \mathrm{IB}{ }^{\text {frg16G-VHSV }}$ for 6, 24 and $48 \mathrm{~h}$. After incubation with IBs, the medium was removed and RBCs were washed with phosphate-buffered saline (PBS). RBCs were then resuspended in $200 \mu \mathrm{L}$ of RPMI $2 \%$ FBS for flow cytometry analysis.

In addition, confocal microscopy was performed to evaluate the uptake of IBs by RBCs. RBCs were incubated with 80 $\mu \mathrm{g} / \mathrm{mL}$ of $\mathrm{IB}^{\mathrm{TNF} \alpha}$ or $160 \mu \mathrm{g} / \mathrm{mL}$ of $\mathrm{IB}^{\text {frg } 16 \mathrm{G}-\mathrm{VHSV}}$ for $24 \mathrm{~h}$. Then, medium was removed and RBCs were washed as indicated above. The RBC nucleus was labeled with $10 \mu \mathrm{g} / \mathrm{mL}$ Hoechst (Sigma-Aldrich) and RBC membrane was stained with $5 \mu \mathrm{g} / \mathrm{mL}$ of CellMask (Thermo Fischer Scientific). Images were taken with a Zeiss LSM 700 microscope (Zeiss, Oberkochen, Germany) and analyzed with Imaris Software v8.2.1 (Bitplane, Zurich, Switzerland). 


\section{RBCs Immune Response After in vitro Treatment With IB ${ }^{\text {TNF } \alpha}$ or IB frg16G-VHSV}

RBCs were treated in vitro with $50 \mu \mathrm{g} / \mathrm{mL}$ of each IB for $24 \mathrm{~h} . \mathrm{IB}^{\mathrm{iRFP}}$ was used as a control. After treatment, RBCs were resuspended in TRK lysis buffer (Omega Bio-Tek Inc., Norcross, GA, USA) and stored at $-80^{\circ} \mathrm{C}$ until RNA extraction.

\section{RBCs Immune Response After in vivo Treatment With IB ${ }^{\text {TNF } \alpha}$ or IB ${ }^{\text {frg } 16 G-v h s v ~}$}

Juvenile rainbow trout $(15-20 \mathrm{~g})$ were treated by intravenous injection in caudal vein with $50 \mu \mathrm{L}$ of IBs $(5.5 \mathrm{mg} / \mathrm{kg})$ or $50 \mu \mathrm{L}$ of PBS. At 24 and $48 \mathrm{~h}$ post-injection fish were sacrificed by overexposure to tricaine. Peripheral blood was sampled as described above and resuspended in RPMI $10 \%$ FBS. Then, RBCs were Ficoll-purified as explained above. Purified RBCs were either resuspended in TRK lysis buffer and stored at $-80^{\circ} \mathrm{C}$ until RNA extraction or fixed for immunofluorescence and flow cytometry, as described below.

In order to track the presence of IBs in vivo, $\mathrm{IB}^{\mathrm{TNF} \alpha}$ was monitored in peripheral blood and head kidney from $\mathrm{IB}^{\mathrm{TNF} \alpha}$ intravenously injected in caudal vein of rainbow trout by means of fluorescent microscopy using IN Cell Analyzer 6,000 Cell Imaging system (GE Healthcare, Little Chalfont, UK). Blood was extracted $3 \mathrm{~h}$ post-injection as described above. Head kidney was aseptically removed, placed in 24 well plates with RPMI $10 \%$

TABLE 1 | List of primers and probes used.

\begin{tabular}{|c|c|c|c|c|}
\hline Gene & Forward primer & Reverse primer & Probe & $\begin{array}{c}\text { Reference or } \\
\text { accession number }\end{array}$ \\
\hline t/r3 & ACTCGGTGGTGCTGGTCTTC & GAGGAGGCAATTGGACGAA & CAAGTTGTCCCGCTGTCTGCTCCTG & $(14)$ \\
\hline $\operatorname{tr} 9$ & CCTGCGACACTTCCTGGTIT & GCCAGTGGTAAGAAGGAGGATCT & CAGACTTCCTGCGTGCCGGCC & $(15,16)$ \\
\hline ifn1 & ACCAGATGGGAGGAGATATCACA & GTCCTCAAACTCAGCATCATCTATGT & AATGCCCCAGTCCTITCCCAAATC & $(14)$ \\
\hline$m \times 1-3$ & TGAAGCCCAGGATGAAATGG & TGGCAGGTCGATGAGTGTGA & АCCTCATCAGCCTAGAGATTGGCTCCCC & $(16)$ \\
\hline il15 & TACTATCCACACCAGCGTCTGAAC & TTCAGCAGCACCAGCAATG & TTCATAATATTGAGCTGCCTGAGTGCCACC & $(14)$ \\
\hline nkef & CGCTGGACTTCACCTITGTGT & ACCTCACAACCGATCTTCCTAAAC & & $(14)$ \\
\hline gstp1 & ССССTCCСTGAAGAGTITGT & GCAGTTCTTGTAGGCGTCAGA & & $(14)$ \\
\hline hepcidin & TCCCGGAGCATTTCAGGTT & GCCCTTGTTGTGACAGCAGTT & & $(14)$ \\
\hline $\operatorname{trx}$ & AGACTTCACAGCCTCCTGGT & ACGTCCACCTTGAGGAAAAC & & $(14)$ \\
\hline il6 & ACTCCCCTCTGTCACACACC & GGCAGACAGGTCCTCCACTA & CCACTGTGCTGATAGGGCTGG & $(17)$ \\
\hline$i / 12 \beta$ & TGACAGCCAGGAATCTTGCA & GAAAGCGAATGTGTCAGTTCAAA & ACCCAACGACCAGCCTCCAAGATG & $(17)$ \\
\hline $\operatorname{tnf} \alpha$ & AGCATGGAAGACCGTCAACGAT & ACCCTCTAAATGGATGGCTGCTT & AAAAGATACCCACCATACATTGAAGCAGATTGCC & $(18)$ \\
\hline il8 & AGAGACACTGAGATCATTGCCAC & СССTCTTCATITGTTGTGGC & TCCTGGCCCTCCTGACCATTACTGAG & $(17,19)$ \\
\hline$i l 1 \beta$ & GCCCCCAACCGCCTTA & CAGTGTTTGCGGCCATCTTA & ACCTTCACCATCCAGCGCCACAA & $(17)$ \\
\hline il2 & GTTGCAGCATTGGCCTGTT & TGTTCTCCTTATCAATCGTCTITTGT & CAACACCACATCAGCATGACTGCCAC & NM_001164065.2 \\
\hline cd83 & TTGGCTGATGATTCTITCGATATC & TGCTGCCAGGAGACACTTGT & TCCTGCCCAATGTAACGGCTGTTGA & $(20)$ \\
\hline mhcl & GACAGTCCGTCCCTCAGTGT & CTGGAAGGTTCCATCATCGT & & $(21)$ \\
\hline mhcll & TGCCATGCTGATGTGCAG & GTCCCTCAGCCAGGTCACT & CGCCTATGACTTCTACCCCAAACAAAT & $(22)$ \\
\hline
\end{tabular}
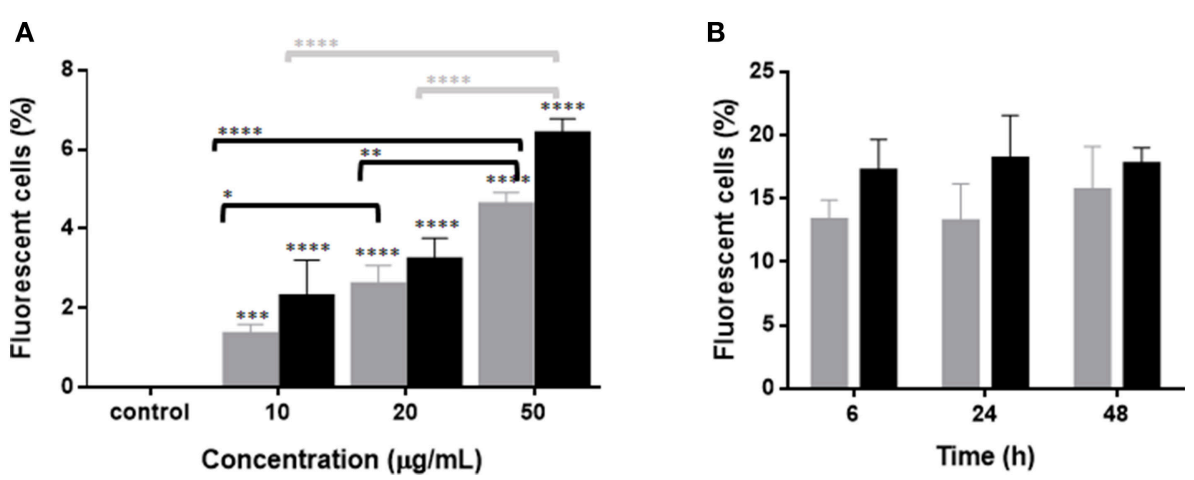

FIGURE 1 | Uptake of IB $\mathrm{B}^{\mathrm{TNF} \alpha}$ and IB frg16G-VHSV by RBCs in vitro. (A) Dose-response of RBCs incubated $24 \mathrm{~h}$ with $10-50 \mu \mathrm{g} / \mathrm{mL}$ IB frg $16 \mathrm{G}-\mathrm{VHSV}$ (gray bars) or $\mathrm{IB}^{\mathrm{TNF} \alpha}$ (black bars). (B) Time course monitoring of RBCs incubated 6, 24, and $48 \mathrm{~h}$ with $160 \mu \mathrm{g} / \mathrm{mL}$ IB frg $16 \mathrm{G}-\mathrm{VHSV}$ (gray bars) or $80 \mu \mathrm{g} / \mathrm{mL}$ IB ${ }^{\mathrm{TNF} \alpha}$ (black bars). Data represent mean \pm SD $(n=4)$. Two-way Anova and Dunnett's multiple comparisons test was performed between all conditions and control (untreated cells) and among concentrations. ${ }^{\star},{ }^{\star \star},{ }^{* \star \star},{ }^{\star \star \star \star} P$-value $<0.05,0.01,0.001$, and 0.0001 , respectively. 
FBS and disaggregated with a Pasteur pipette and passed through a Falcon $40 \mu \mathrm{m}$ nylon cell strainer (BD Biosciencies) using a plunger of a $5 \mathrm{ml}$ syringe.

\section{RNA Isolation, cDNA Synthesis, RT-qPCR, and Gene Expression Analysis}

RBCs total RNA was extracted as previously described (14) using E.Z.N.A. ${ }^{\circledR}$ Total RNA Kit (Omega Bio-Tek Inc.). DNAse treatment was performed in order to eliminate residual genomic DNA using $\mathrm{TURBO}^{\mathrm{TM}}$ DNase (Ambion, Thermo Fischer Scientific Inc.). Then cDNA synthesis and RT-qPCR was performed as described in Nombela et al (14). Primers and probes used are listed in Table 1. Gene expression was analyzed by means of the $2^{-\Delta \mathrm{Ct}}$ or $2^{-\Delta \Delta \mathrm{Ct}}$ (23) using 18S rRNA (Applied Biosystems, Thermo Fischer Scientific Inc.) as endogenous gene. Principal component analysis (PCA) and clustering heatmap of immune-gene expression data $\left(2^{-\Delta \mathrm{Ct}}\right.$ or $\left.2^{-\Delta \Delta \mathrm{Ct}}\right)$ were performed using Clustvis software (24). For PCA, unit variance scaling was applied to rows and singular value decomposition (SVD) with imputation was used to calculate principal components. For clustering heatmap, columns were collapsed by taking mean inside each group, rows were centered, and unit variance scaling was applied to rows; then, imputation was used for missing value estimation; and, both rows and columns were clustered using correlation distance and average linkage.

\section{Immunofluorescence Assays}

Purified RBCs were fixed as previously described (14), using 4\% paraformaldehyde (PFA; Sigma-Aldrich) and $0.008 \%$ glutaraldehyde (GA, Sigma-Aldrich) in RPMI

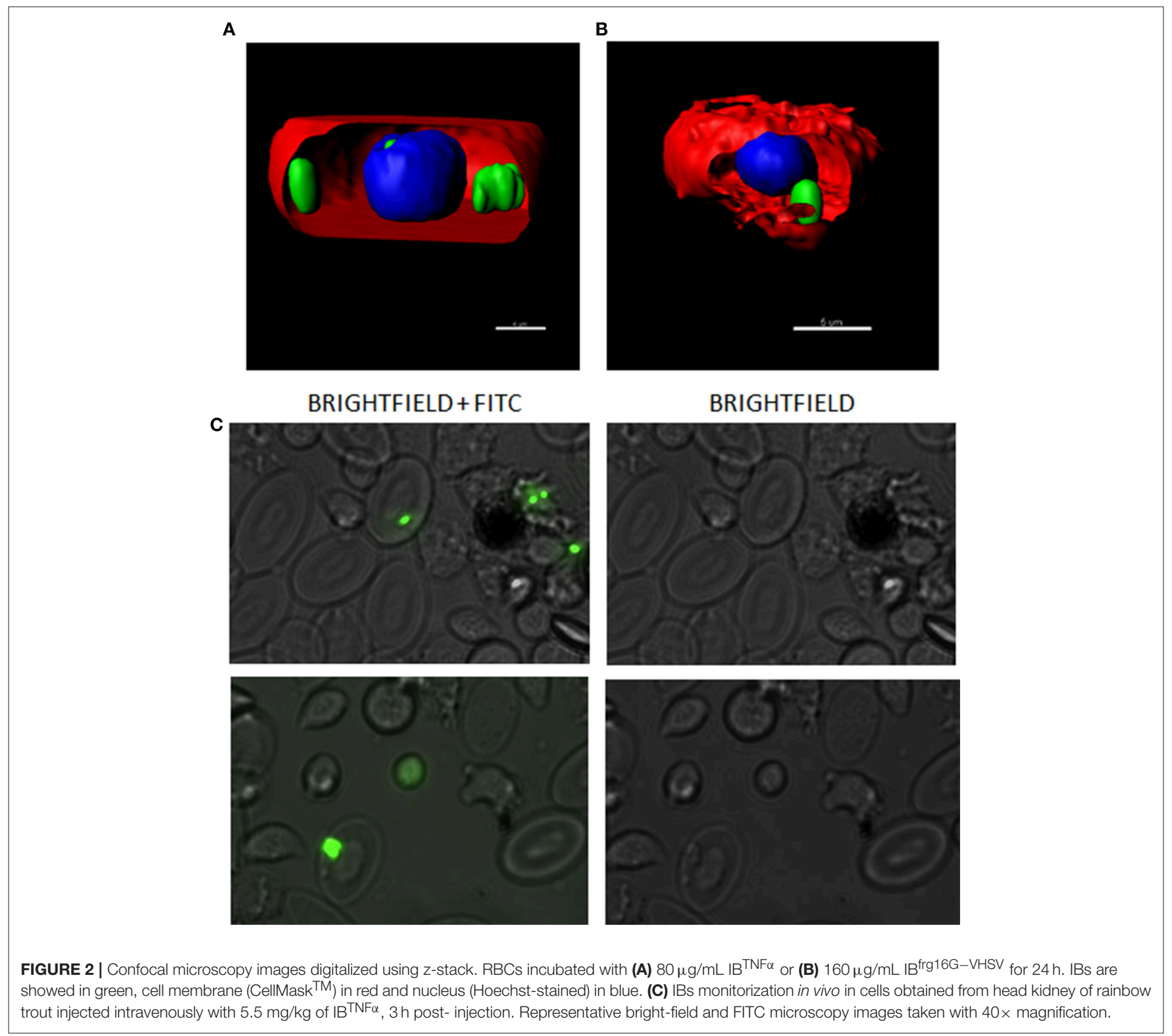


medium. Anti-MX (25, 26) and anti-IL8 (27) were used as primary antibodies and goat- $\mathrm{CF}^{\mathrm{TM}} 647$ anti-mouse $\mathrm{IgG}$ $(\mathrm{H}+\mathrm{L})$ and goat- $\mathrm{CF}^{\mathrm{TM}} 647$ anti-rabbit $\operatorname{IgG}(\mathrm{H}+\mathrm{L})$ antibodies (Sigma-Aldrich) were used as secondary antibodies. Nuclear staining was performed with $1 \mu \mathrm{g} / \mathrm{mL}$ of $4^{\prime}-6$ Diamidino-2-phenylindole (DAPI, Sigma-Aldrich). Images were captured in an IN Cell Analyzer 6000 Cell Imaging system. Flow cytometry was carried out in a FACSCanto ${ }^{\mathrm{TM}}$ flow cytometer.

\section{Software and Statistics}

Graphpad Prism 6.01 (www.graphpad.com) was used for statistics and graphic representation. Statistic tests and $P$ values associated with graphics are indicated in each assay. Flow cytometry data was processed and analyzed using Flowing Software 2.5.1 (www.flowingsoftware.com/). Principal component analysis (PCA) and clustering of gene expression analysis was performed using ClustVis software (https://biit.cs. ut.ee/clustvis/) (24).

\section{RESULTS}

\section{Uptake of IB ${ }^{\text {TNF } \alpha}$ and IB frg16G-VHSV by RBCs}

In order to evaluate the interaction between RBCs and IBs, we performed a dose-response and time-course evaluation by means of flow cytometry. According to our results, all IB concentrations assayed showed uptake or attachment to RBCs, which increased with IB concentration (Figure 1A). The percentage of IB positive cells ranged from 5 to $7 \%$ at $50 \mu \mathrm{g} / \mathrm{mL}$ after $24 \mathrm{~h}$ incubation. Time course evaluation at 6,24 , and $48 \mathrm{~h}$ showed no differences in IB load in RBCs (Figure 1B) indicating that the maximum IB internalization or attachment occurred by $6 \mathrm{~h}$ of incubation. However, the time course was carried out with a higher dose and up to $17 \%$ of fluorescent positive cells were detected. This was maximum percentage uptake achieved under our experimental conditions. The level of uptake of $\mathrm{IB}^{\mathrm{TNF} \alpha}$ by RBCs was observed to be higher than $\mathrm{IB}^{\mathrm{frg} 16 \mathrm{G}-\mathrm{VHSV}}$ when comparing the same concentration of both IBs (Figure 1A). IB uptake was confirmed by confocal $3 \mathrm{D}$ images, which showed the internalization of $\mathrm{IB}^{\mathrm{TNF} \alpha}$ (Figure 2A) and IB frg16G-VHSV (Figure 2B) in the cytosol of RBCs.

The presence of $\mathrm{IB}^{\mathrm{TNF} \alpha}$ in $\mathrm{RBCs}$ was monitored in vivo in peripheral blood and head kidney cells by fluorescent microscopy using intravenously injected $\mathrm{IB}^{\mathrm{TNF} \alpha}$. In blood, few RBCs were found to carry the IB ${ }^{\mathrm{TNF} \alpha}$ (data not shown); however, RBCs carrying $\mathrm{IB}^{\mathrm{TNF} \alpha}$ were easily found in head kidney cells extracts (Figure 2C).

\section{Immune Response of RBCs Induced After Exposure to $\mathrm{IB}^{\mathrm{TNF} \alpha}$ or IB ${ }^{\text {frg16G-VHSV }}$ in vitro}

To explore the immune response triggered by IBs in RBCs in vitro, RBCs were treated with $50 \mu \mathrm{g} / \mathrm{mL}$ of $\mathrm{IB}^{\mathrm{TNF} \alpha}, \mathrm{IB}^{\text {frg16G-VHSV }}$ or IB ${ }^{\text {iRFP }}$ and RNA was extracted at $24 \mathrm{~h}$ post-treatment. IB $^{\mathrm{TNF} \alpha}$ tended to down-regulate the genes tested in RBCs at $24 \mathrm{~h}$ post-treatment. This down-regulation was statistically significant in genes related to antigen presentation $(c d 83, m h c I)$ and antioxidant gene gstp1. On the other hand, only the antioxidant
TABLE 2 | Immune-gene expression analysis of RBCs stimulated in vitro with $50 \mu \mathrm{g} / \mathrm{mL}$ of IB $\mathrm{B}^{\text {iRFP }}$, IB ${ }^{\text {TNF } \alpha}$ and IB Irg $16 \mathrm{G}-\mathrm{VHSV}$ at $24 \mathrm{~h}$ post-treatment.

\begin{tabular}{|c|c|c|c|c|}
\hline & \multicolumn{2}{|c|}{ IB $^{\text {TNF } \alpha}$} & \multicolumn{2}{|c|}{ IB $^{\text {frg16G-VHSV }}$} \\
\hline & Mean & SD & Mean & SD \\
\hline$m x$ & 0.902 & 0.157 & 1.013 & 0.199 \\
\hline il15 & 0.943 & 0.288 & 1.181 & 0.414 \\
\hline cd83 & $0.782^{\star \star \star}$ & 0.042 & 0.918 & 0.101 \\
\hline mhel & $0.794^{\star}$ & 0.138 & 0.899 & 0.145 \\
\hline mhcll & 0.965 & 0.235 & 1,270 & 0.428 \\
\hline nkef & 1.106 & 0.753 & 1.067 & 0.943 \\
\hline gstp1 & $0.785^{\star \star}$ & 0.105 & 1.254 & 0.588 \\
\hline $\operatorname{trx}$ & 1.070 & 0.179 & $1.289^{\star \star}$ & 0.316 \\
\hline trr3 & 0.866 & 0.163 & 0.887 & 0.198 \\
\hline $\operatorname{tr} 9$ & 0.814 & 0.656 & 0.907 & 0.623 \\
\hline
\end{tabular}

RBCs were Ficoll-purified and treated with IBs. $24 \mathrm{~h}$ post-treatment gene expression was analyzed by RT-qPCR, $2^{-\Delta \Delta C t}$ method, normalized to the endogenous gene eukaryotic $18 S$, and relative to control cells (treated with IB ${ }^{\text {RFP }}$ ). Data represent mean fold change \pm $S D(n=4)$. Mann-Whitney test was performed between each condition and control cells. ${ }^{*},{ }^{* *},{ }^{* \star *} P$-value $<0.05,0.01$, and 0.001 respectively.

trx gene was significantly up-regulated in $\mathrm{IB}^{\mathrm{frg}} 16 \mathrm{G}-\mathrm{VHSV}$ treated RBCs at 24 h post-treatment (Table 2 ).

In order to analyse the gene expression of RBCs in response to each treatment as a whole, multivariate analyses of the gene expression data matrix were performed. A principal component analysis (PCA) plot of the gene expression profile showed a differentiated population of RBCs treated with $\mathrm{IB}^{\mathrm{TNF} \alpha}$ or $\mathrm{IB}^{\text {frg16G-VHSV }}$ compared to $\mathrm{IB}^{\mathrm{iRFP}}$ (Figure 3A). This is also appreciable in the clustering heatmap (Figure 3B), where the mean values of molecular (gene expression) signatures are clustered. The heatmap data matrix visualizes the values in the cells by the use of a color gradient which gives an overview of the largest and smallest values in the matrix (24).

\section{Immune-Gene and Protein Expression Modulation in RBCs From Peripheral Blood After in vivo Treatment With IB ${ }^{\mathrm{TNF} \alpha}$ or IB frg16G-VHSV}

Rainbow trout were intravenously injected to evaluate the immune response triggered by IBs in RBCs of peripheral blood in vivo. RBCs were sampled at 24 and $48 \mathrm{~h}$ post-injection. In general, the results showed, as in vitro, a down-regulatory trend in the gene expression of $\mathrm{IB}^{\mathrm{TNF} \alpha}$ treated individuals compared to $\mathrm{IB}^{\mathrm{iRFP}}$ treated individuals. It should be noted that $c d 83$ was significantly down-regulated at $24 \mathrm{~h}$ post-injection (Figure 4A), as occurred in vitro. On the other hand, il6 was significantly up-regulated at $24 \mathrm{~h}$ post-injection. Further, $\operatorname{tr} 9$, ifn $1, i l 1 \beta$, $i l 2, m h c I I$ and nkef genes were significantly down-regulated at $48 \mathrm{~h}$ post-injection (Figure $4 \mathrm{~B}$ ). In contrast, $\mathrm{IB}^{\text {frg } 16 \mathrm{G}-\mathrm{VHSV}}$ treated individuals showed an up-regulatory trend at both 24 and $48 \mathrm{~h}$ post-injection, compared to $\mathrm{IB}^{\mathrm{iRFP}}$, with significant up-regulation of cytokines il2 and il6, and antioxidant gene $n k e f$ at $24 \mathrm{~h}$ post-injection, and of $t l r 3$, interferon inducible 

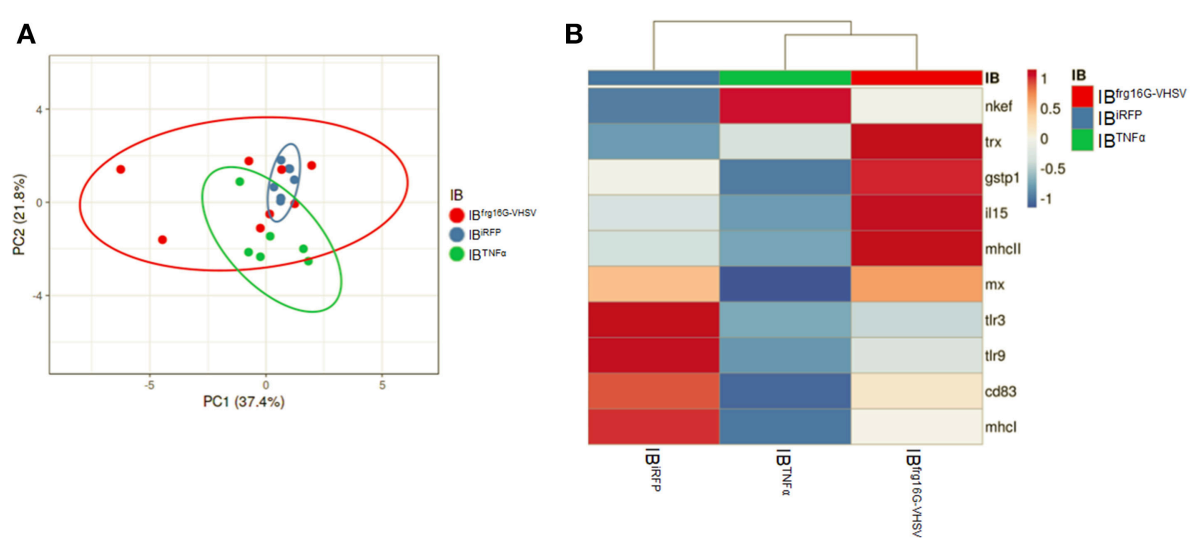

FIGURE 3 | Principal component analysis (PCA) of immune-gene expression evaluation of RBCs stimulated in vitro with $50 \mu \mathrm{g} / \mathrm{mL}$ of IB ${ }^{i R F P}$, IB ${ }^{T N F} \alpha$, or $\mathrm{IB}^{\text {frg } 16 \mathrm{G}-\mathrm{VHSV}}$, at $24 \mathrm{~h}$ post-treatment. (A) PCA plot of molecular (gene expression data, $2^{-\Delta \Delta \mathrm{Ct}}$ ) signatures of IB ${ }^{\mathrm{iRFP}}$, IB ${ }^{\mathrm{TNF} \alpha}$, or IB frg $16 \mathrm{G}-\mathrm{VHSV}$ treated samples, at $24 \mathrm{~h}$ post-treatment. Ellipses and shapes show clustering of the samples. (B) Heatmap of molecular (gene expression data, $2^{-\Delta \Delta C t}$ ) signatures of IB ${ }^{\text {iRFP }}$, IB ${ }^{T N F} \alpha$, or $\mathrm{IB}^{\text {frg16G-VHSV }}$ treated samples. Annotations on top of the heatmap show clustering of the samples, mean values. PCA plot and heatmap were performed using Clustvis software. Heatmap data matrix visualizes the values in the cells using a color gradient which gives an overview of the largest and smallest values in the matrix.

$m x, c d 83$, and $m h c I I$ at $48 \mathrm{~h}$ post-injection (Figures $4 \mathrm{~A}, \mathbf{B}$, Table S1). However, $m x$ gene appeared down-regulated at $24 \mathrm{~h}$ post-injection. Separately, most of the genes were upregulated with all the treatments in comparison with PBSinjection.

The gene expression profile PCA plot depicted differentiated populations for RBCs from individuals treated with $\mathrm{IB}^{\mathrm{TNF} \alpha}$ or $\mathrm{IB}^{\text {frg16G-VHSV }}$ compared to $\mathrm{IB}^{\mathrm{iRFP}}$ (Figures 5A, 6A, for 24 and $48 \mathrm{~h}$ post-injection, respectively), which was also observed in the clustering heatmap (Figures 5B, 6B, for 24 and $48 \mathrm{~h}$ post-injection respectively). In addition, at $48 \mathrm{~h}$ postinjection, MX and IL8 protein levels, evaluated by means of flow cytometry, showed an increment, but not statistically significant, in MX (Figures 7A,C) and IL8 (Figures 7B,D) in $\mathrm{RBCs}$ from rainbow trout treated with $\mathrm{IB}^{\text {frg16G-VHSV }}$ in relation to PBS-injected or the other IBs assayed. This result correlates with the $m x$ gene expression at $48 \mathrm{~h}$ in vivo. On the other hand, the protein levels of MX and IL8 in $\mathrm{RBCs}$ from $\mathrm{IB}^{\mathrm{TNF} \alpha}$ treated rainbow trout were slightly lower than $\mathrm{IB}^{\mathrm{iRFP}}$ and PBS-injected individuals (only showing statistical significance for $\mathrm{MX}$ between $\mathrm{IB}^{\mathrm{TNF} \alpha}$ and $\mathrm{IB}^{\mathrm{iRFP}}$ treatments), which is consistent with the down-regulatory trend observed in $\mathrm{IB}^{\mathrm{TNF} \alpha}$ treated $\mathrm{RBCs}$ in vivo and in vitro at the transcriptional level. Moreover, in whole peripheral blood, a similar tendency was observed in MX protein expression, although more pronounced in this case. Note, however, for IL8 protein levels, we did not observe any difference among groups (Figures 8A,B).

\section{DISCUSSION}

Recently, IBs have been reported as new alternatives in fish prophylaxis as immunostimulants or adjuvants (10), thus potentially serving as a new platform for vaccine delivery. The uptake of IBs has been reported in rainbow trout macrophages (RT-HKM) and zebrafish liver cells (ZFL). In both cell types IBs made with cytokines stimulate the innate immune response (9). Moreover, IBs made with fish viral antigens have evoked an anti-viral innate immune response in ZFL and RT-HKM (12). However, the immune response of nucleated RBCs to nanostructured cytokine or viral antigen IBs has not been tested until now. Nucleated RBCs are the main cell in the blood and recently have been endorsed as immune cells mediators $(6,28)$. In this work we show that the uptake or attachment of IBs by rainbow trout RBCs occurred in approximately $7 \%$ of cells counted. This contrasts to the near $40 \%$ and $80 \%$ reported for ZFL and RT-HKM, respectively, at same concentration $(50 \mu \mathrm{g} / \mathrm{mL})$ of $\mathrm{IB}^{\mathrm{TNF} \alpha}(9)$. RBCs endocytosed both the IBs tested here reaching their maximum level at $6 \mathrm{~h}$ post-treatment, in contrast to RT-HKM and ZFL cell lines, which reached their maximum uptake at $24 \mathrm{~h}$ post-treatment in vitro (10). Besides, monitorization of $\mathrm{IB}^{\mathrm{TNF} \alpha}$ in vivo demonstrated its presence on/in RBCs from head-kidney $3 \mathrm{~h}$ post-injection. The mechanism by which RBCs endocytose IBs is unknown. It may occur via the micropinocytosis endocytic pathway, as proposed for mammalian cells (29).

Significantly, with this work, we add to the growing body of data demonstrating nucleated RBCs can exercise a role in the immune response. RBCs are able to respond to virus $(6,14,30)$, produce cytokines when exposed to stimuli (17), and endocytose pathogens (2). Here we show for the first time rainbow trout RBCs evoke an immune response to IBs made of cytokine $\mathrm{TNF} \alpha$ and viral protein frg16G-VHSV in vitro and in vivo. We demonstrate this response at protein and transcript level. Rainbow trout Ficoll-purified RBCs treated with IBs in vitro and RBCs Ficoll-purified from blood extracts from IB-intravenously injected individuals modulated the expression of genes related to antigen presentation, cytokines and other genes involved in the immune response. PCA clearly clustered the RBCs' immune-gene expression profiles for each treatment. 


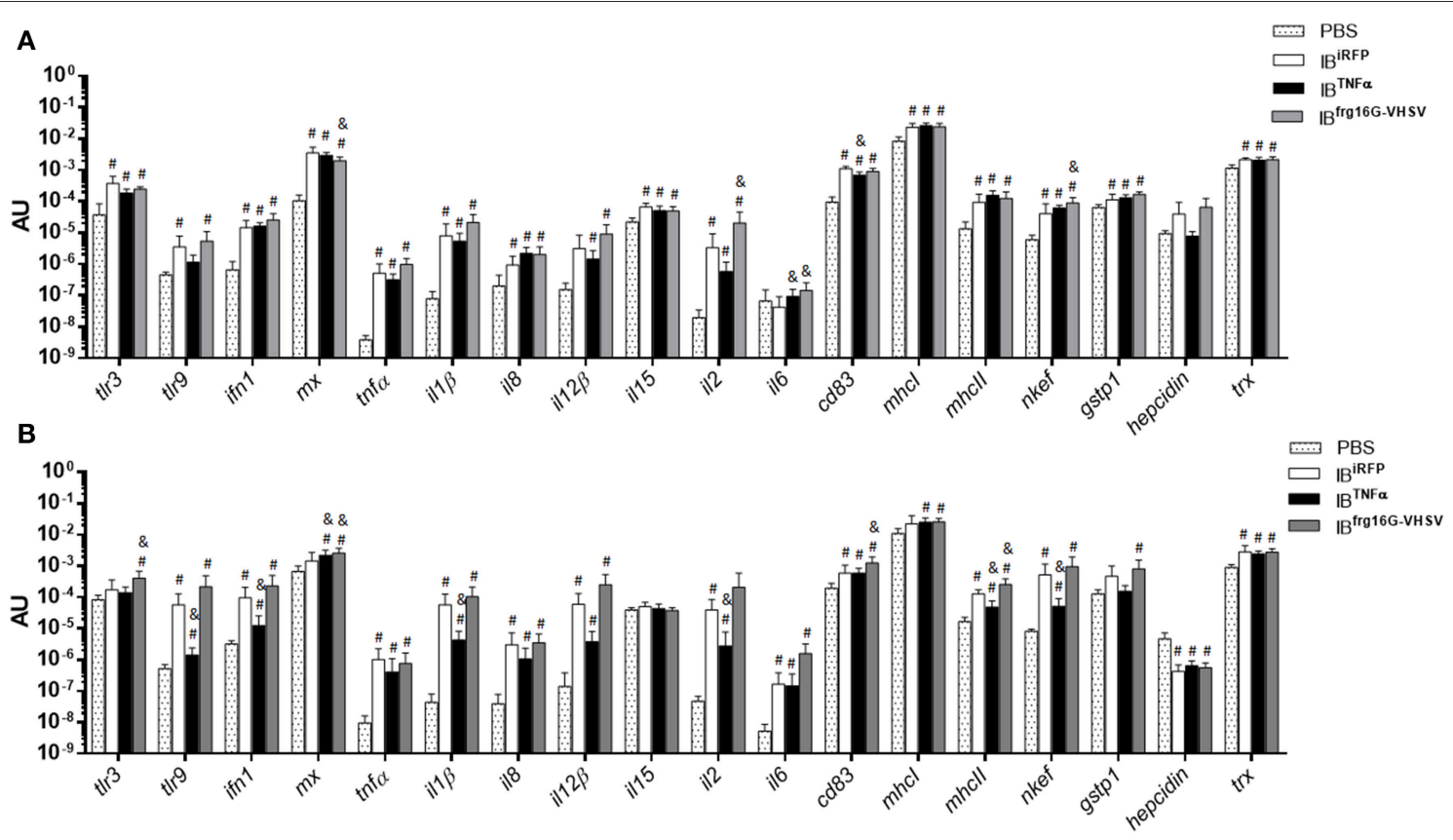

FIGURE 4 | Immune-gene expression analysis of RBCs from rainbow trout injected intravenously with PBS, IB ${ }^{\text {iRFP }}$, IB ${ }^{\text {TNF } \alpha}$, or IB frg16G-VHSV at 24 and $48 \mathrm{~h}$ post-injection. Rainbow trout of 15-20 g were injected with $5.5 \mathrm{mg} / \mathrm{kg}$ of IB intravenously. Blood was extracted and RBCs Ficoll-purified $24 \mathrm{~h}$ (A) and $48 \mathrm{~h}$ (B) post-injection. Gene expression was analyzed by RT-qPCR, $2^{-\Delta C t}$ method, with endogenous gene eukaryotic $18 \mathrm{~S} r \mathrm{RNA}$. Data represent mean AU (arbitrary units) \pm $\mathrm{SD}(n=4)$. Mann-Whitney test was performed between each condition and control (treated with PBS or IB ${ }^{\mathrm{IRFP}}$ ). \#P-value $<0.05$, compared to PBS; \& $P$-value $<$ 0.05 , compared to IB ${ }^{i R F P}$

A

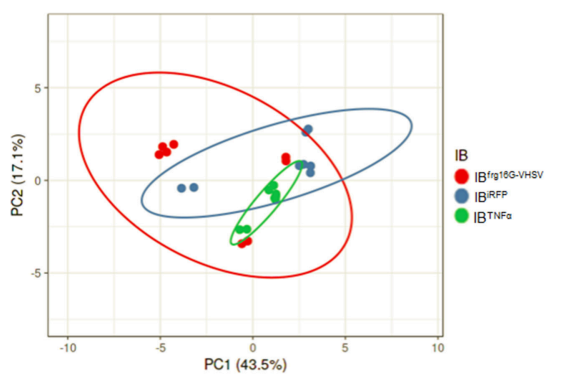

B

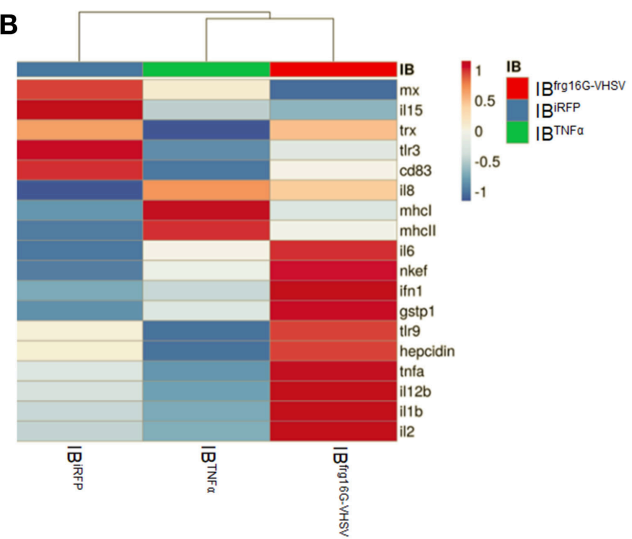

FIGURE 5 | Principal component analysis (PCA) of immune-gene expression evaluation of RBCs from rainbow trout injected intravenously with IB ${ }^{i R F P}$, IB ${ }^{T N F} \alpha$, or

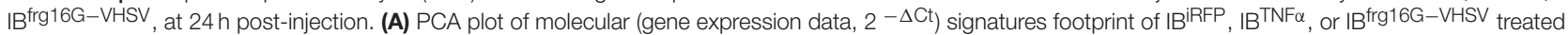
samples, at $24 \mathrm{~h}$ post-injection. Ellipses and shapes show clustering of the samples. (B) Heatmap of gene expression (2 $\left.-\Delta \mathrm{Ct}^{\prime}\right)$ signatures of IB $^{\mathrm{iRFP}}$, IB ${ }^{\mathrm{TNF} \alpha}$, or IB frg16G-VHSV treated samples. Annotations on top of the heatmap show clustering of the samples mean values. PCA plot and heatmap was performed using Clustvis software. Heatmap data matrix visualizes the values in the cells using a color gradient which gives an overview of the largest and smallest values in the matrix.

As regards $\mathrm{TNF} \alpha$, $\mathrm{RBCs}$ from $\mathrm{IB}^{\mathrm{TNF} \alpha}$-treated rainbow trout individuals showed a down-regulatory trend for genes related to $\mathrm{TNF} \alpha$ signaling such as $\operatorname{tr} 9, \operatorname{tn} f \alpha, i l 1 \beta, i l 12 \beta$, and $i l 2$ genes transcripts, in vivo, at 24 and $48 \mathrm{~h}$ post-injection, compared to fish injected with the non-immunogenic protein $I^{i R F P}$. It is known that $\mathrm{TNF} \alpha$ is a cytokine involved in the regulation of immune cells and inflammation. It is mainly produced by monocytes and macrophages along with additional producers including $\mathrm{B}$ and $\mathrm{T}$ lymphocytes, NK cells, polymorphonuclear leukocytes, and eosinophils in response to bacterial toxins, inflammatory products, and other invasive stimuli (31). Recently, nucleated RBCs have been also reported to modulate $\mathrm{TNF} \alpha$ 
A

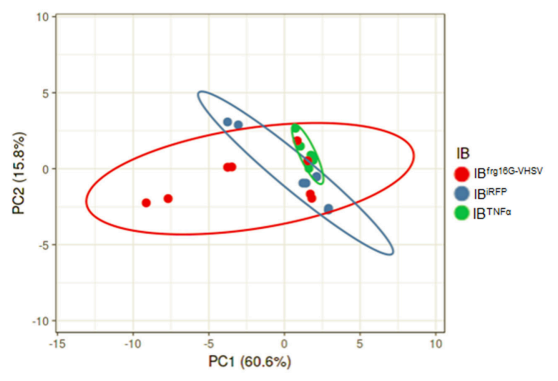

B

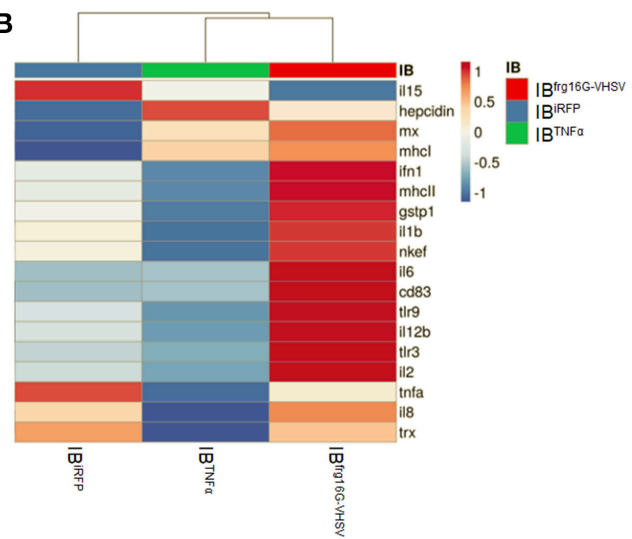

FIGURE 6 | Principal component analysis (PCA) of immune-gene expression evaluation of RBCs from rainbow trout injected intravenously with IB ${ }^{i R F P}$, IB ${ }^{\text {TNF } \alpha}$, or

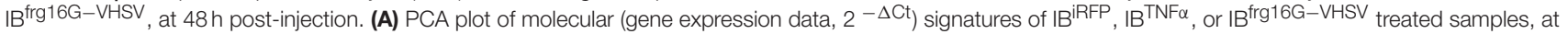
$48 \mathrm{~h}$ post-injection. Ellipses and shapes show clustering of the samples. (B) Heatmap of molecular (gene expression data, $2^{-\Delta C t}$ ) signatures of IB ${ }^{i R F P}$, IB ${ }^{T N F} \alpha$, or $^{-1}$ IB frg16G-VHSV treated samples. Annotations on top of the heatmap show clustering of the samples mean values. PCA plot and heatmap was performed using Clustvis software. Heatmap data matrix visualizes the values in the cells using a color gradient which gives an overview of the largest and smallest values in the matrix.

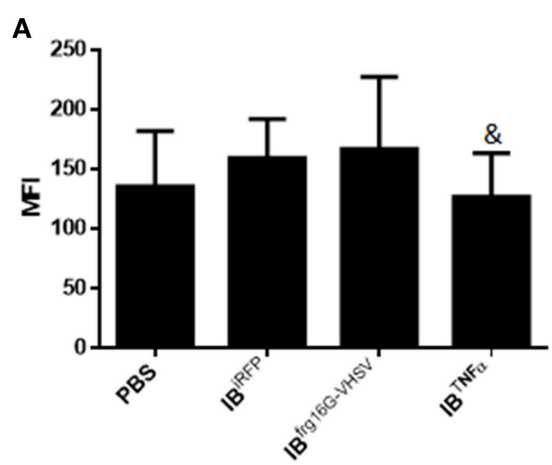

C
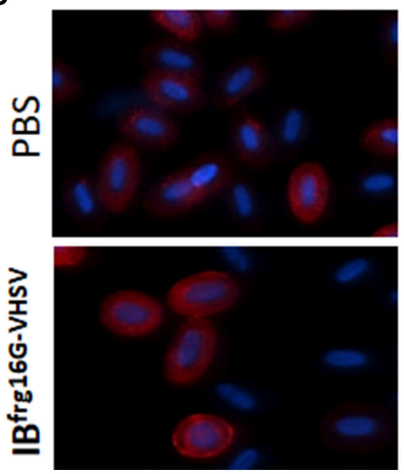

B

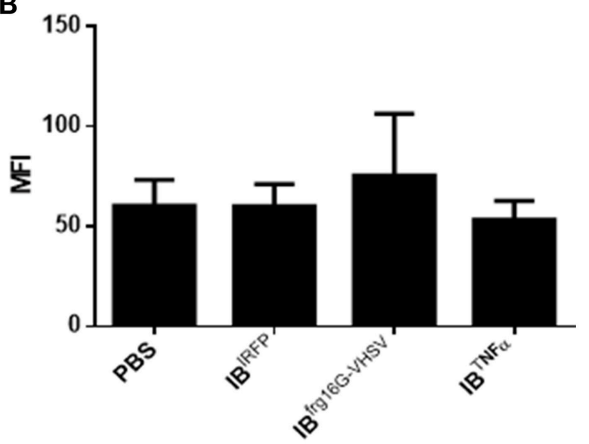

D
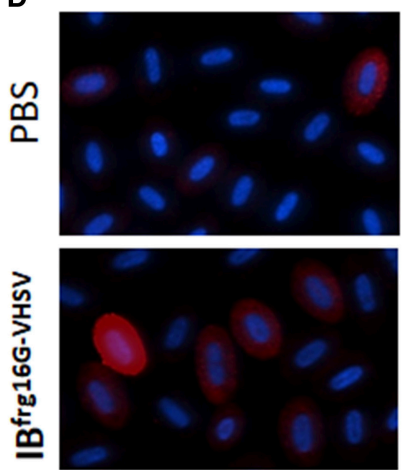

FIGURE 7 | Protein expression analysis of RBCs from rainbow trout injected intravenously with $5.5 \mathrm{mg} / \mathrm{kg}$ of IB ${ }^{\mathrm{iRFP}}$, IB ${ }^{\mathrm{TNF} \alpha}$, IB ${ }^{\text {frg } 16 G-V H S V}$ or PBS at $48 \mathrm{~h}$ post-injection. (A) Interferon related protein MX and (B) chemokine IL8 Mean Fluorescence Intensity (MFI) measured by flow cytometry. Data represent mean \pm SD ( $n$ =4). Mann-Whitney test was performed between each condition and control cells (treated with PBS or IB ${ }^{\text {iRFP }}$ ). \&P-value $<0.05$, compared to IB ${ }^{i R F P}$. Representative immunofluorescence images of RBCs stained with (C) anti-MX and (D) anti-IL8, taken with 60× magnification. Protein stain in red, DAPI (blue) for nuclei stain.

protein in response to IPNV virus exposure (30). Here we observed that RBCs exposed to $\mathrm{IB}^{\mathrm{TNF} \alpha}$ down-regulated the inflammatory response at 24 and $48 \mathrm{~h}$ post-treatment. TNF $\alpha$ is a pleiotropic cytokine with a diverse range of biological actions. TNF family members are known to represent a "doubleedged sword," having both beneficial and detrimental activities 
A

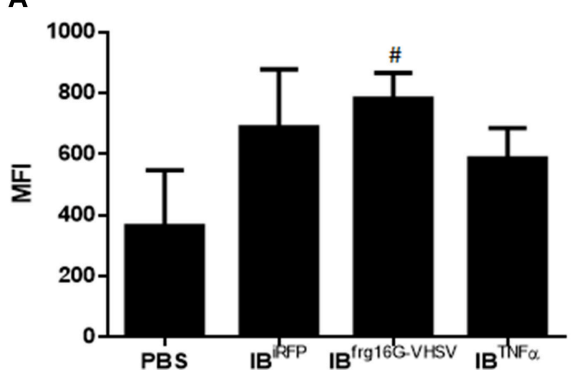

B

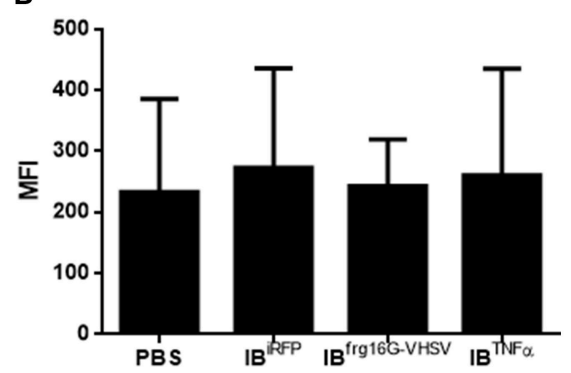

FIGURE 8 | Protein expression analysis of total blood samples from rainbow trout injected intravenously with 5.5 mg/kg of IBiRFP, IB ${ }^{\text {TNF } \alpha}$, IB frg $16 G-V H S V$, and PBS at $48 \mathrm{~h}$ post-injection. (A) Interferon related protein MX and (B) chemokine IL8 Mean Fluorescence Intensity (MFI) measured by flow cytometry. Data represent mean \pm SD $(n=4)$. Mann-Whitney test was performed between each condition and control cells (treated with PBS or IB ${ }^{i R F P}$ ). \#P-value $<0.05$, compared to PBS.

(32). Systemic exposure to recombinant $\mathrm{TNF} \alpha$ would cause a shock similar to septic shock syndrome (31). Further, TNF $\alpha$ inhibition of IFN $\gamma$-induced IL12 production exerts mechanisms by which TNF $\alpha$ and IL12 cytokines can elicit anti-inflammatory and repair functions, tightly modulated by positive and negative feedback signals for optimal immunity without manifested inflammation (33). Another important observation is that fish recombinant $\mathrm{TNF} \alpha$ has been reported to regulate the expression of endothelial cells TLRs, including TLR9, but had negligible effects on macrophages (34). Therefore, taking into account that nucleated RBCs are the most abundant cell type in peripheral blood, it would make sense that RBCs were equipped to modulate inflammation in response to a systemic exposure to TNF $\alpha$. Moreover, in the $\mathrm{IB}^{\mathrm{TNF} \alpha}$ injected group, genes related to antigen presentation, $c d 83$ and $m h c I I$, were also down-regulated at 24 and $48 \mathrm{~h}$, respectively. As well, RBCs treated in vitro with $\mathrm{IB}^{\mathrm{TNF} \alpha}$ down-regulated the expression of $c d 83$ and $m h c I 24 \mathrm{~h}$ posttreatment. TNF $\alpha$ has been reported to modulate IFN $\gamma$-induced MHC class II expression in a cell type-specific mode (35). Therefore, TNF $\alpha$ treatment augments or blocks MHC class II induction depending on the cell type and cellular differentiation state (35). $m h c I I$ and $c d 83$ gene expression has been previously reported for rainbow trout $\operatorname{RBCs}(3,36)$ and chicken RBCs $(37)$. However, this is the first report that shows the regulation of $c d 83$ and $m h c I I$ gene transcripts in response to an immunostimulant.

On the other hand, RBCs from rainbow trout injected with $\mathrm{IB}^{\text {frg16G-VHSV }}$ showed an up-regulatory trend for most of the genes, specifically interleukins $i l 2$ and il6, and antioxidant enzyme $n k e f$ were significantly up-regulated, compared to IB ${ }^{\mathrm{iRFP}}$, at $24 \mathrm{~h}$ post-injection. This is probably due to the effort of RBCs to compensate the inflammatory response triggered after the first treatment stimulus. Then, $48 \mathrm{~h}$ post-injection, the Type $1 \mathrm{IFN}$ and antigen presentation responses were increased, since $t \operatorname{lr} 3, m x$, $c d 83$, and $m h c I I$ genes transcripts were significantly up-regulated, compared to $\mathrm{IB}^{\mathrm{iRFP}}$. MX protein production was consistent with gene expression levels.

G-VHSV is known to induce the expression of ifn 1 and $m x(25,38,39)$. Peptides derived from G-VHSV have also demonstrated their efficacy to induce type 1 IFN response (25, $26,39)$. It is also noteworthy that $\mathrm{IB}^{\text {frg } 16 \mathrm{G}-\mathrm{VHSV}}$ triggered the up-regulation of $m h c I I$ and $c d 83$ gene expression in rainbow trout RBCs, thus endowing them the characteristics of antigen presenting cells (APCs). CD83 and MHCII are principally produced by professional APCs to process antigens and induce T cell priming. However, recently, the concept of non-professional APCs is emerging (40). These atypical APCs up-regulate the expression of $\mathrm{MHC}$ and related molecules under certain stimuli. However, there is not enough evidence about their functionality priming T cells (40).

Bacterial lipopolysaccharide has been reported to stimulate the innate immune response of RBCs in vitro (28). Bacterial IBs, which contain remnants of endotoxin, are therefore considered immunostimulants per se (41), which is shown by the global increment in the immune response of RBCs from rainbow trout injected with $\mathrm{IB}^{\mathrm{iRFP}}$ compared to PBS-injection. This, added to the utilization of IBs as delivery platforms to administrate cytokines, coadjuvants, or antigens, makes them a good candidate for future vaccines. In this context, RBCs have shown their ability to mount or modulate and immune-response to IBs made of cytokine $\mathrm{TNF} \alpha$ and the viral protein frg16G-VHSV.

All these considerations provide a new perspective on the role and potential use of RBCs. Given the large amount of RBCs in the organism and their rapid distribution throughout the body they could be a promising target cell for the presentation or delivery of IBs or other types of vaccine carriers.

\section{ETHICS STATEMENT}

Experimental protocols and methods of the experimental animals at the UMH were reviewed and approved by the Animal Welfare Body and the Research Ethics Committee at the University Miguel Hernandez (approval number 2014.205.E.OEP; 2016.221.E.OEP) and by the competent authority of the Regional Ministry of Presidency and Agriculture, Fisheries, Food and Water supply (approval number 2014/VSC/PEA/00205). All methods were carried out in accordance with the Spanish Royal Decree RD 53/2013 and EU Directive 2010/63/EU for the protection of animals used for research experimentation and other scientific purposes. All experimental procedures of 
the experimental animals at the UAB were approved by the Human and Animal Experimentation Ethics Committee of the Universitat Autònoma de Barcelona (Reference 1533) and were done in strict accordance with the recommendations of the European Directive (2010/63/EU) on the protection of animals used for scientific purposes.

\section{AUTHOR CONTRIBUTIONS}

SP-M performed experiments, analyzed data, and wrote the manuscript. RT performed experiments and contributed to manuscript preparation. JC contributed to $\mathrm{IB}^{\text {frg } 16 \mathrm{G}-\mathrm{VHSV}}$ construction. LM provided valuable antibodies for the experiments. NR conceived ideas, oversaw the research and contributed to manuscript preparation. MO-V conceived ideas, oversaw the research and co-wrote the manuscript.

\section{FUNDING}

This work was supported by the European Research Council fund to MO-V (ERC Starting Grant GA639249)

\section{REFERENCES}

1. Glomski CA, Tamburlin J, Chainani M. The phylogenetic odyssey of the erythrocyte. III. Fish, the lower vertebrate experience. Histol Histopathol. (1992) 7:501-28.

2. Passantino L, Massaro MA, Jirillo F, Di Modugno D, Ribaud MR, Modugno GD, et al. Antigenically activated avian erythrocytes release cytokine-like factors: a conserved phylogenetic function discovered in fish. Immunopharmacol Immunotoxicol. (2007) 29:141-52. doi: 10.1080/08923970701284664

3. Puente-Marin S, Nombela I, Ciordia S, Mena MC, Chico V, Coll J, et al. In silico functional networks identified in fish nucleated red blood cells by means of transcriptomic and proteomic profiling. Genes. (2018) 9:E202. doi: 10.3390/genes9040202

4. Morera D, Roher N, Ribas L, Balasch JC, Donate C, Callol A, et al. RNA-Seq reveals an integrated immune response in nucleated erythrocytes. PLOS ONE. (2011) 6:e26998. doi: 10.1371/journal.pone.0026998

5. Workenhe ST, Kibenge MJ, Wright GM, Wadowska DW, Groman DB, Kibenge FS. Infectious salmon anaemia virus replication and induction of alpha interferon in Atlantic salmon erythrocytes. Virol J. (2008) 5:36. doi: 10.1186/1743-422X-5-36

6. Nombela I, Ortega-Villaizan M. Nucleated red blood cells: immune cell mediators of the antiviral response. PLoS Pathog. (2018) 14 :e1006910. doi: 10.1371/journal.ppat.1006910

7. Holvold LB, Myhr AI, Dalmo RA. Strategies and hurdles using DNA vaccines to fish. Vet Res. (2014) 45:21. doi: 10.1186/1297-9716-45-21

8. OIE. Chapter 2.3.10: Viral Haemorrhagic Septicaemia. In: Manual of Diagnostic Tests for Aquatic Animals. OIE, editor (2017). Available online at: http://www.oie.int/en/standard-setting/aquatic-manual/access-online/.

9. Torrealba D, Parra D, Seras-Franzoso J, Vallejos-Vidal E, Yero D, Gibert I, et al. Nanostructured recombinant cytokines: a highly stable alternative to short-lived prophylactics. Biomaterials. (2016) 107:10214. doi: 10.1016/j.biomaterials.2016.08.043

10. Torrealba D, Seras-Franzoso J, Mamat U, Wilke K, Villaverde A, Roher N, et al. Complex particulate biomaterials as immunostimulant-delivery platforms. PLoS ONE. (2016) 11:e0164073. doi: 10.1371/journal.pone.0164073

11. Encinas P, Gomez-Casado E, Estepa A, Coll JM. An ELISA for detection of trout antibodies to viral hemorrhagic septicemia virus using recombinant and by grants from the Spanish Ministry of Science, European commission and AGAUR funds to NR (AGL2015-65129-R MINECO/FEDER and 2014SGR345 AGAUR). RT holds a pre-doctoral scholarship from AGAUR (Spain).

\section{ACKNOWLEDGMENTS}

The authors would like to thank Remedios Torres and Efren Lucas for their technical assistance and Nuria Barba from the Servei de Microscopia and Manuela Costa from the Servei de Citometria of the Universitat Autònoma de Barcelona for helpful technical assistance. We are also thankful to the two reviewers for their valuable and constructive comments and corrections.

\section{SUPPLEMENTARY MATERIAL}

The Supplementary Material for this article can be found online at: https://www.frontiersin.org/articles/10.3389/fimmu. 2019.01055/full\#supplementary-material

fragments of their viral G protein. J Virol Methods. (2011) 176:1423. doi: 10.1016/j.jviromet.2011.05.018

12. Thwaite R, Ji J, Torrealba D, Coll J, Sabès M, Villaverde A, et al. Protein nanoparticles made of recombinant viral antigens: a promising biomaterial for oral delivery of fish prophylactics. Front Immunol. (2018) 9:1652. doi: 10.3389/fimmu.2018.01652

13. Filonov GS, Piatkevich KD, Ting LM, Zhang J, Kim K, Verkhusha VV. Bright and stable near-infrared fluorescent protein for in vivo imaging. Nat Biotechnol. (2011) 29:757-61. doi: 10.1038/nbt.1918

14. Nombela I, Puente-Marin S, Chico V, Villena AJ, Carracedo B, Ciordia S, et al. Identification of diverse defense mechanisms in rainbow trout red blood cells in response to halted replication of VHS virus. F1000Research. (2017) 6:1958. doi: 10.12688/f1000research.12985.1

15. Ortega-Villaizan M, Chico V, Falco A, Perez L, Coll JM, Estepa A. The rainbow trout TLR9 gene and its role in the immune responses elicited by a plasmid encoding the glycoprotein G of the viral hemorrhagic septicaemia rhabdovirus (VHSV). Mol Immunol. (2009) 46:1710-7. doi: 10.1016/j.molimm.2009.02.006

16. Ortega-Villaizan M, Chico V, Martinez-Lopez A, Falco A, Perez L, Coll $\mathrm{JM}$, et al. In vitro analysis of the factors contributing to the antiviral state induced by a plasmid encoding the viral hemorrhagic septicaemia virus glycoprotein G in transfected trout cells. Vaccine. (2011) 29:73743. doi: 10.1016/j.vaccine.2010.11.021

17. Chico V, Puente-Marin S, Nombela I, Ciordia S, Mena MC, Carracedo B, et al. Shape-shifted red blood cells: a novel red blood cell stage? Cells. (2018) 7:E31. doi: 10.3390/cells7040031

18. Purcell MK, Nichols KM, Winton JR, Kurath G, Thorgaard GH, Wheeler P, et al. Comprehensive gene expression profiling following DNA vaccination of rainbow trout against infectious hematopoietic necrosis virus. Mol Immunol. (2006) 43:2089-106. doi: 10.1016/j.molimm.2005.12.005

19. Wang T, Bird S, Koussounadis A, Holland JW, Carrington A, Zou J, et al. Identification of a novel IL-1 cytokine family member in teleost fish. J Immunol. (2009) 183:962-74. doi: 10.4049/jimmunol.0 802953

20. Ortega-Villaizan M, Martinez-Lopez A, Garcia-Valtanen P, Chico V, Perez L, Coll JM, et al. Ex vivo transfection of trout pronephros leukocytes, a model for cell culture screening of fish DNA vaccine candidates. Vaccine. (2012) 30:5983-90. doi: 10.1016/j.vaccine.2012.07.013 
21. Chaves-Pozo E, Montero J, Cuesta A, Tafalla C. Viral hemorrhagic septicemia and infectious pancreatic necrosis viruses replicate differently in rainbow trout gonad and induce different chemokine transcription profiles. Dev Comp Immunol. (2010) 34:648-58. doi: 10.1016/j.dci.2010.01.009

22. Jorgensen TR, Raida MK, Kania PW, Buchmann K. Response of rainbow trout (Oncorhynchus mykiss) in skin and fin tissue during infection with a variant of Gyrodactylus salaris (Monogenea: Gyrodactylidae). Folia Parasitol. (2009) 56:251-8. doi: 10.14411/fp.2009.029

23. Livak KJ, Schmittgen TD. Analysis of relative gene expression data using realtime quantitative PCR and the 2(-Delta Delta C(T)) Method. Methods. (2001) 25:402-8. doi: 10.1006/meth.2001.1262

24. Metsalu T, Vilo J. ClustVis: a web tool for visualizing clustering of multivariate data using Principal Component Analysis and heatmap. Nucleic Acids Res. (2015) 43:W566-70. doi: 10.1093/nar/gkv468

25. Chico V, Martinez-Lopez A, Ortega-Villaizan M, Falco A, Perez L, Coll JM, et al. Pepscan mapping of viral hemorrhagic septicemia virus glycoprotein $\mathrm{G}$ major lineal determinants implicated in triggering host cell antiviral responses mediated by type I interferon. J Virol. (2010) 84:714050. doi: 10.1128/JVI.00023-10

26. Martinez-Lopez A, Garcia-Valtanen P, Ortega-Villaizan M, Chico V, GomezCasado E, Coll JM, et al. VHSV G glycoprotein major determinants implicated in triggering the host type I IFN antiviral response as DNA vaccine molecular adjuvants. Vaccine. (2014) 32:6012-9. doi: 10.1016/j.vaccine.2014.07.111

27. Mercado L, Santana P, Palacios C, Narváez E, Guzmán F, Gallardo JA. Antipeptide antibodies: a tool for detecting IL-8 in salmonids. Elect $J$ Biotechnol. (2012) 15:20. doi: 10.2225/vol15-issue5-fulltext-15

28. Morera D, MacKenzie SA. Is there a direct role for erythrocytes in the immune response? Vet Res. (2011) 42:89. doi: 10.1186/1297-9716-42-89

29. Seras-Franzoso J, Sanchez-Chardi A, Garcia-Fruitos E, Vazquez E, Villaverde A. Cellular uptake and intracellular fate of protein releasing bacterial amyloids in mammalian cells. Soft Matter. (2016) 12:3451-60. doi: 10.1039/C5SM02930A

30. Nombela I, Carrion A, Puente-Marin S, Chico V, Mercado L, Perez L, et al. Infectious pancreatic necrosis virus triggers antiviral immune response in rainbow trout red blood cells, despite not being infective. F1000Research. (2017) 6:1968. doi: 10.12688/f1000research.12994.2

31. Ma X. TNF-alpha and IL-12: a balancing act in macrophage functioning. Microbes Infect. (2001) 3:121-9. doi: 10.1016/S1286-4579(00)01359-9

32. Aggarwal BB. Signalling pathways of the TNF superfamily: a doubleedged sword. Nat Rev Immunol. (2003) 3:745-56. doi: 10.1038/ nri1184

33. Hodge-Dufour J, Marino MW, Horton MR, Jungbluth A, Burdick MD, Strieter RM, et al. Inhibition of interferon gamma induced interleukin 12 production: a potential mechanism for the anti-inflammatory activities of tumor necrosis factor. Proc Natl Acad Sci USA. (1998) 95:1380611. doi: 10.1073 /pnas.95.23.13806

34. Roca FJ, Mulero I, Lopez-Munoz A, Sepulcre MP, Renshaw SA, Meseguer J, et al. Evolution of the inflammatory response in vertebrates: fish TNF-alpha is a powerful activator of endothelial cells but hardly activates phagocytes. $J$ Immunol. (2008) 181:5071-81. doi: 10.4049/jimmunol.181.7.5071

35. Han Y, Zhou ZH, Ransohoff RM. TNF-alpha suppresses IFN-gamma-induced MHC class II expression in HT1080 cells by destabilizing class II transactivator mRNA. J Immunol. (1999) 163:1435-40.

36. Puente-Marin S, Nombela I, Chico V, Ciordia S, Mena MC, Coll J, et al. Rainbow Trout Erythrocytes ex vivo transfection with a DNA vaccine encoding VHSV Glycoprotein G induces an antiviral immune response. Front Immunol. (2018) 9:2477. doi: 10.3389/fimmu.2018.02477

37. St Paul M, Paolucci S, Barjesteh N, Wood RD, Sharif S. Chicken erythrocytes respond to Toll-like receptor ligands by up-regulating cytokine transcripts. Res Vet Sci. (2013) 95:87-91. doi: 10.1016/j.rvsc.2013.01.024

38. Acosta F, Collet B, Lorenzen N, Ellis AE. Expression of the glycoprotein of viral hemorrhagic septicaemia virus (VHSV) on the surface of the fish cell line RTG-P1 induces type 1 interferon expression in neighbouring cells. Fish Shellfish Immunol. (2006) 21:272-8. doi: 10.1016/j.fsi.2005.12.006

39. Ortega-Villaizan M, Chico V, Martinez-Lopez A, Garcia-Valtanen P, Coll JM, Estepa A. Development of new therapeutical/adjuvant molecules by pepscan mapping of autophagy and IFN inducing determinants of rhabdoviral G proteins. Mol Immunol. (2016) 70:118-24. doi: 10.1016/j.molimm.2015.10.008

40. Kambayashi T, Laufer TM. Atypical MHC class II-expressing antigenpresenting cells: can anything replace a dendritic cell? Nat Rev Immunol. (2014) 14:719-30. doi: 10.1038/nri3754

41. Garcia-Fruitos E. Inclusion bodies: a new concept. Microbial Cell Factor. (2010) 9:80. doi: 10.1186/1475-2859-9-80

Conflict of Interest Statement: The authors declare that the research was conducted in the absence of any commercial or financial relationships that could be construed as a potential conflict of interest.

Copyright (C) 2019 Puente-Marin, Thwaite, Mercado, Coll, Roher and OrtegaVillaizan. This is an open-access article distributed under the terms of the Creative Commons Attribution License (CC BY). The use, distribution or reproduction in other forums is permitted, provided the original author(s) and the copyright owner(s) are credited and that the original publication in this journal is cited, in accordance with accepted academic practice. No use, distribution or reproduction is permitted which does not comply with these terms. 